\title{
Submission guidelines
}

\section{Editorial purpose}

College \& Research Libraries News (CERL News) publishes articles written by practitioners addressing the philosophy and techniques of day-to-day management of academic library services and collections.

CERL News provides current information relating to issues, activities, and personalities of the higher education and academic/research library field. Trends and developments in user education, technology, professional education, preservation, public relations, products, acquisitions of special collections, grants to libraries, governmental actions affecting libraries, and reports on meetings are covered in CERL News.

Established in 1966, CERL News is the official news magazine and publication of record of the Association of College and Research Libraries (ACRL). It maintains a record of selected actions and policy statements of the association and publishes timely reports on the activities of ACRL and its units. It is published 11 times per year.

The editor bears full responsibility for the content of each issue of CERL News and selects material for publication based on the following criteria. The editor also reserves the right to make appropriate revisions in material selected for publication in order to standardize style or improve clarity (except official ACRL documents).

Note: Formal, theoretical, or research-oriented articles inappropriate for CGRL Neus will be forwarded to the editor of College $\xi$ Research Libraries for review.

\section{Instructions to authors}

1. Style. Articles should be practical and written in an informal, accurate, and informative manner. Manuscripts should be original and not published elsewhere. (Exceptions may be made for items previously published in institutional newsletters.) Footnotes, charts, and tables should be kept to a minimum.

2. Length. News notes may be 150-350 words; reports of meetings for the "Conference Circuit" should be 750-1,000 words; essays for "The Way I See It" should be 750 words; and articles should be no more than 2,000 words.

3. Content. Material selected should fall into one of the following categories:

a. Reports on a project, program, or service dealing with a topic relevant to academic librarianship (e.g., "Improving valid access to site-licensed resources," November 1997). b. Reports for "Conference Circuit" that summarize the highlights of a recent conference, work shop, or meeting of interest to academic or research librarians (e.g. "The scholarly monograph in crisis," November 1997)

c. Essays for "The Way I See It" that offer reasoned and informed speculation or comment on relevant topics (e.g., "Another look at staffing the reference desk," November 1997).

d. Essays for "Every Librarian a Leader" that share practical examples of how librarians can serve in leadership roles (e.g., "There must be 50 ways to be a leader," April 1996).

e. Standards, guidelines, or recommendations of an ACRL committee or other official ACRL group (e.g., "Standards for college libraries," April 1995).

f. Essays for "Focus on Libraries" that describe new and renovated libraries and innovative library services. (e.g. "User education at NYPL's new SIBL," October 1997)

g. CERL News may occasionally print requests for the donation of books or materials to libraries, especially foreign libraries, which have suffered extensive loss through fire, hurricane, or natural disaster. Other libraries soliciting contributions for other reasons will be referred to the rates for classified advertising in CERL News.

4. Grapbics. Whenever possible, photographs, illustrations, images from Web sites, etc., should accompany article submissions. Authors are responsible for obtaining permission to use graphic materials. Submit camera-ready artwork for all illustrations. On the back of each photograph include: a brief caption, credits (if appropriate), and your name, address, phone number, and e-mail.

5. Stubmitting manuscripts. Authors should submit two copies, double-spaced, following The Chicago Manual of Style, 14 th ed, to CERL News Editor, ALA, 50 E. Huron, Chicago, IL 60611. (Note: An e-mail note of inquiry may precede submission of the article.) If the manuscript is prepared on a word processor, please supply an electronic version of the manuscript as a text file in an IBM-compatible format, preferably in WordPerfect for Windows 6.0 or ASCII. Note: Please label 3.5" disks with your name, phone number, e-mail, and filename. Manuscripts may also be submitted via the Internet: medavis@ala.org.

Ed note: These guidelines were reviewed and adopted by the CERL News Editorial Board in the fall of 1997 